\title{
Investigating the Effect of Reduced Forms Instruction on EFL Learners' Listening and Speaking Abilities
}

\author{
Mohammad Saber Khaghaninezhad $^{1}$ \& Ghasem Jafarzadeh ${ }^{2}$ \\ ${ }^{1}$ Department of Foreign Languages and Linguistics, Shiraz University, Iran \\ ${ }^{2}$ Islamic Azad University, Science and Research Branch of Boushehr, Iran \\ Correspondence: Mohammad Saber Khaghaninezhad, Department of Foreign Languages and Linguistics, Shiraz \\ University, Iran. Tel: 98-711-613-4511. Email: mskhaghani@shirazu.ac.ir
}

\author{
Received: September 21, 2013 Accepted: October 31, 2013 Online Published: December 5, 2013 \\ doi:10.5539/elt.v7n1p159 URL: http://dx.doi.org/10.5539/elt.v7n1p159
}

\begin{abstract}
Listening comprehension is usually considered as one of the most difficult language skills to EFL learners due to the unavoidable presence of "reduced forms" in authentic speech. This study was an attempt to investigate the effect of explicit "reduced forms" instruction on Iranian EFL learners' overall listening comprehension and their ability to recognize and produce them in their daily conversations. The participants of this study were 50 intermediate English learners who were randomly assigned as the experimental and the control groups of the study. Three pre-tests were administered at the commencement of the study to see if the participants of both groups were at the same level of listening comprehension and "reduced forms" awareness. After the pre-tests, the participants in the experimental group received instruction on "reduced forms" while the control participants continued their regular classes. At the end of the 10-week instruction, the participants were given three post-tests to see if they have improved their listening comprehension ability and their ability to recognize and produce the "reduced forms" recurrently in their daily speech. Although the control participants have significantly improved their listening comprehension, the fact that the experimental participants had outperformed implied the efficacy of "reduced forms" training on the overall listening comprehension's betterment. The results also revealed that the experimental participants significantly improved their "reduced forms" awareness as well as their ability to produce "reduced forms" at the end of training course while the control participants didn't.
\end{abstract}

Keywords: "Reduced forms" recognition and production, listening difficulty, "reduced forms" instruction

\section{Introduction}

Despite the fact that listening has an important role in language learning, it is still the most neglected language skill. Moreover, learners recognize listening as the most difficult skill to acquire, it is said that L2 listening comprehension has remained the least researched of all four language skills (Vandergrift, 2007). In order to develop listening skill of EFL learners, language acquisition researchers and language teachers have explored listening strategies using a variety of methods, including think-aloud procedures (Chamot \& Kupper, 1989; O’Malley, Chamot \& Kupper, 1989), listening strategies inventories (Fujita, 1985), questionnaires (Fujita, 1985; Goh, 2002; Vandergrift, 2002, 2005), recall task (Moreira, 1996; Schmidt, 2002), and diaries (Goh, 1997).

Some researchers believe that EFL learners would not be able to improve their listening skill, because most of the instructional materials used in the classrooms are simplified and unnatural, no matter how different the employed techniques are, the instructional materials lack the strength to cover how the real listening process occurs (e.g. Brown \& Yule, 1983; Rosa, 2002). Therefore, being exposed to the modified and unnatural language used in the classrooms, the learners often fail to comprehend the real language used by native speakers or the authentic one they hear during watching movies or listening to radio.

Considering the interdependence of speaking and listening abilities and the vital role of oral skills in interacting in a second or a foreign language, this study attempted to find out whether the explicit instruction of the English "reduced forms" as one of the key components of the spoken English has any effect on the improvement of the overall listening comprehension of the Iranian EFL learners and their ability to recognize and use the "reduced forms" in their daily vocalizations. In fact, this study was an attempt to find reasonable answers to the following questions: 
1) Is there a significant difference between Iranian EFL learners who have experienced explicit instruction of English "reduced forms" and those who have not in terms of overall listening comprehension?

2) Does instructing English "reduced forms" explicitly increase Iranian EFL learners' ability to recognize them in the spoken language?

3) Does teaching English "reduced forms" explicitly enable Iranian EFL learners to produce them in their own daily verbalizations?

\section{Literature Review}

\subsection{Background}

Today, listening is considered as an active skill that involves many processes, but researchers believe that although listening comprehension is now recognized as an important aspect of language learning and consequently social interaction, much work remains to be done. As Brown (1987) mentioned, a significant number of published courses on listening comprehension and classroom practices in many schools in many countries continues to demonstrate that listening is still regarded as the least important skill in language teaching. And yet, despite a gradually increasing acceptance of the importance of listening comprehension for second/foreign language learners, innovations in the realm of listening comprehension are very rare if there is any in ESL or EFL programs, the so-called "Cinderella skill" (Mandelsohn, 1994; Nunan, 1997; Vandergrift, 1997).

There has been a growing body of research on the role of authentic materials on FL teaching in recent years. Researchers and teachers increasingly acknowledged the need for and usefulness of authentic materials in the field of language teaching in general and oral skills, in particular (Khalilisabet \& Masefat, 2012). Rivers (1981) explained that all instructional materials used for listening comprehension, even in the earliest lessons, should be authentic, that is, it should consist of utterances with a high probability of occurrence. Teaching students to comprehend artificial language combinations which would rarely be heard from a native speaker is a waste of time and energy, and can only confuse students when later confronted with natural speech.

Empirical studies have substantiated the positive results taken by learners who have opportunities to interact and deal with authentic texts. Vandergrift (2007) argued in favor of using authentic materials as the best option, since the ultimate goal of second language learners is to understand the language that is used in real life communication. Studies, such as Miller (2005) and Thanajaro (2000), revealed that incorporating authentic materials lead to aural language development. In addition, Al-Musallam (2009) investigated the impact of aural authentic texts on listening comprehension abilities of four adult ESL students at an American university. He concluded that exposure to authentic materials would lead to improving students' listening comprehension abilities and motivation. By the same token, conducting on intermediate-level students, Herron and Seay (1991) found that those students who listened to authentic radio tapes as a substitute for regular classroom activities demonstrated significantly greater listening comprehension than those students for whom the authentic radio program was not a part of the semester's curriculum. Their research confirmed that, the more exposure to authentic speech the more improvement in listening-comprehension skill. They listed the main advantages of using authentic listening materials as follows,

1) They have a positive effect on learner motivation.

2) They provide authentic cultural information and exposure to real language.

3) They relate more closely to learners 'needs.

4) They support a more creative approach to teaching.

Field (1997) explained that learners find it extremely motivating to hear something that has not been simplified: they felt that they are getting to grips with real language, and Newton (2009, p. 172) contends that "authentic texts can be motivating because they are proof that the language is used for real- life purpose by real people".

Critics of authentic materials, on the other hand, disputed the effectiveness on several grounds. Richards (2006) mentioned that authentic materials (a) created materials may be superior to authentic materials because they are generally built around a graded syllabus, (b) authentic materials often contain difficult and irrelevant language and (c) using authentic materials is a burden for teachers. Rost (2001) stated: "Authentic texts from one culture may give a false impression to a student from another unless they are presented in an authentic context which makes it clear precisely what they exemplify" (p. 49). In sum, the idea of authenticity in language teaching has been debated over the past three decades. However, the benefits that authentic materials bring to the FL classroom may be said to greatly outweigh the difficulties they might give rise to. In addition, it is possible to 
overcome such challenges through task design. Researchers such as Field (1998) and Richards and Renandya (2002) recommend that: "instead of simplifying the language of the text, simplify the task that is demanded of the student. ... with the text above the language level of the class, one demands only shallow comprehension" ( $p$. 244). Undoubtedly, authentic materials used for ameliorating the oral language skills more or less incorporate "reduced forms" as one of the prominent features.

\section{2 "Reduced Forms"}

The term "reduced forms" is taken from Brown and Hilferty (1986) and refers to the phenomenon of phonological simplification and variation commonly observed in the informal speech of native speakers. According to Cele-Murica, Brinton, and Goodwin (1996) "reduced forms" involve unstressed vowels, omitted sounds, and other alternation of the full form". Researchers use different terms to refer to the same phenomenon (Crystal, 1997) called such forms "sandhi forms", Ur (1984) called them "weak forms" or Goh (2002) called "connected speech".

Brown and Kondo-Brown (2006) mentioned that "connected speech" makes up "a very real part of the spoken language and occurs in all levels of speech from casual to even very formal levels" (p. 5). The naturally occurring speech of native speakers is mostly rapid and continuous with frequent linking, sound alteration, or reduction at word boundaries, which may cause comprehension difficulty when non-native speakers listen to it. Ito (2006) described how non-native speakers would find "connected speech" very different from what they would have normally heard before in language classrooms, where the speech from teachers and audio materials are typically carefully or slowly articulated. Goh (2002) and Chen (2002) claimed that students do not recognize words they know while listening to native speakers. Sun (2002) also made a similar suggestion that students cannot segment speech, and that makes listening difficult. Rosa (2002) explained that natural English, whether formal or informal, fast or slow, is full of these "reduced forms", and this creates a serious obstacle for students who have little or no exposure to "reduced forms". Table1 presents English "reduced forms" as listed by Brown and kondo-Brown (2006):

Table 1. English reduced forms listed by Brown and Kondo-Brown (2006)

\begin{tabular}{|c|c|c|}
\hline Type & Description & Example \\
\hline Reduced forms & $\begin{array}{l}\text { They are the spontaneous pronunciation changes in adjacent } \\
\text { words or sounds spoken at a natural speed. }\end{array}$ & $\begin{array}{l}\text { /gonna/, /wanna/, /hafta/, } \\
\text { /gotta/ }\end{array}$ \\
\hline Contraction & $\begin{array}{l}\text { This is a written manifestation of a small set of words which } \\
\text { are often used in written dialogue to give a spoken flavor. }\end{array}$ & $\begin{array}{l}\text { I'm, don't, she's, they'll, } \\
\text { we're, you'd }\end{array}$ \\
\hline Elision & $\begin{array}{l}\text { It occurs when a sound is omitted and it is a typical feature } \\
\text { of "connected speech". Despite the fact that in a word } \\
\text { spoken in isolation a sound would be present, in "connected } \\
\text { speech" it would disappear. This kind of reduction occurs } \\
\text { mainly in words ending with } / \mathrm{t} / \text { and } / \mathrm{d} / \text { and particularly } \\
\text { when they are between two other consonants. }\end{array}$ & $\begin{array}{l}\text { Omission of } / t / \text { in "last } \\
\text { night": /læsnaIt/ } \\
\text { Omission of /d/ in "old } \\
\text { man": /oulmæn/ }\end{array}$ \\
\hline Reduction & $\begin{array}{l}\text { When the vowels found in unstressed syllables are reduced } \\
\text { to schwa } / \curvearrowright / \text {. }\end{array}$ & Could: /kəd/ \\
\hline Assimilation & $\begin{array}{l}\text { It is an important feature of English in which a phoneme } \\
\text { changes its quality due to the influence of a neighboring } \\
\text { sound. }\end{array}$ & Don't you: /dont $\int \mathrm{a} /$ \\
\hline
\end{tabular}

Researchers also speak about benefits of producing "connected speech". Dauer and Brown (1992) argued that producing "connected speech" can be beneficial in many ways because it enables the speaker to not only improve his or her intelligibility by developing overall speech rhythm, but also brings psychological relief and confidence as it causes speech to sound more natural. Not using "connected speech" might even cause a non-native speaker's speech to sound unnatural and choppy, and could bring about frustration to the listener (Celce-Murcia et al., 1996).

\subsection{Why to Instruct "Reduced Forms"?}

Henrichsen (1984) investigated how the presence/absence of "sandhi-variation", another term referring to 
"reduced forms", influence ESL learners' comprehension of input. He found a statistically significant interaction between proficiency level and the learners' test scores for presence/absence of "sandhi-variation" and estimated that about $35 \%$ of all words produced in natural speech can be reduced. Ting and Pierce (2011) further confirmed that the presence of "reduced forms" was a direct factor affecting the achievement of EFL English majors' listening comprehension. Instructing the "reduced forms" has thus been advocated as a means to remove the obstacle of improvement.

In spite of their substantial occurrence in spoken discourse, "reduced forms" are definitely not easy for EFL learners. "Reduced forms" are considered by many researchers (e.g. Brown, 1987; Brown \& Yule, 1983; Henrichsen, 1984; Ur, 1984) to be one of the reasons that make dividing the stream of speech difficult, and in turn make comprehension inaccessible. Norris (1995, p. 67) explained the difficulty as follows:

When students who come from English learning backgrounds in which they got used to slow speech are often shocked when they find themselves in a situation in which native speakers are talking to each other. In this situation, they have difficulty in understanding what is said.

The positive effects of teaching the "reduced forms" on listening comprehension have also been reported in the Japanese EFL context. Romanko (2008) found that teaching English "reduced forms" significantly improved Japanese freshman's ability to recognize "reduced forms" on a post-course test of listening ability. He also found that two months after the end of the course, 107 participants were able to demonstrate retention of most of their previously acquired knowledge without any controlled exposure to "reduced forms" occurring in the meantime.

Kuo (2012) proposed a film-based learning system to aid learners' listening comprehension of "reduced forms". The system could not only extract the "reduced forms" in the films but also automatically developed cloze tests based on the extracted materials. Chang (2004) and Matsuzawa (2006) said about the positive effects of teaching "reduced forms" on the listening comprehension of the English language learners. They explained that while there are only a limited number of studies investigating the effects of "reduced forms" on listening ability, their results showed that teaching "reduced forms" leads to an improvement in listening comprehension of the English learners.

Cahill (2006) also elaborated on the importance of teaching "English reduced forms" to Japanese EFL learners. He mentioned that if teachers do not adequately prepare students for authentic international situations, they are doing their students a disservice. This lack of exposure may prevent Japanese EFL learners from developing a fuller range of listening-comprehension skills. D. Brown and K. Brown (2007, p. 5) pronounced the benefits of teaching "reduced forms" as follows:

1) "Reduced forms" are very real part of language.

2) Students need to learn more than the traditional grammar, vocabulary, and pronunciation that many language teachers present; "reduced forms" are important subsets of the new information they need to learn.

3) Students need to be able to adjust their styles and registers in using language; the ability to understand and use "reduced forms" is essential for making such adjustments.

4) "Reduced forms" are not just lazy, sloppy, careless, or slovenly language; rather, they occur in all levels of speech, including the most formal manners of speaking.

Not many researchers have studied the role of teaching "reduced forms" on perception, and fewer have investigated the role of instructing "reduced forms" on production of intelligible and natural language. Although Anderson-Hsieh, Riney, and Koehler's (1994) research did examine the production of "reduced forms", the study was more about examining how native speakers and non-native speakers differ in the amount of "connected speech" produced, rather than investigating the effectiveness of instruction on overall pronunciation ability. The results revealed that the higher level students produced more "connected speech" modifications that were closer to those of English native speakers than the lower level students. More studies are needed in order to understand the benefits of learning how to produce "connected speech" and not to mention more inquiries examining the teachability of "reduced forms".

\section{Method}

\subsection{Participants}

Participants of the study were 50 male Iranian EFL learners who were studying English at Zaban-sara, a private language institution. All of the participants were studying general English, and were Farsi native speakers. Their age ranged from 16 to 37 . The majority of the participants were 16 to 20 years old, whereas thirteen of them were 20 to 25 , nine were $25-30$, and the remaining seven participants were $30-37$ years old. The participants 
were classified into two groups randomly as the control and experimental groups of the study; each group consisted of 25 learners.

\subsection{Instruments}

In order to answer the research questions, the following tests were used to collect the needed data:

General English listening comprehension test: To answer the first research question, and to see the possible difference between Iranian EFL learners who have experienced explicit teaching of English "reduced forms" (experimental participants) and those who have not (control participants) in terms of listening comprehension, a reliable, and valid listening comprehension test was given to the participants as the pre-test and post-test, and the performances of the both groups were compared. The listening test consisted of two videos selected from the video book of the Four Corners 4 by Richards and Bohlke (2012) - a total of 26 listening items containing answering questions, true or false items, matching activity, completing the incomplete sentences with correct words and multiple choice items.

"Reduced forms" recognizing test: In order to answer the second research question a fill-in-the-blank dictation test consisting of 20 "reduced forms" statements served as the "reduced forms" pre and post-tests. In the "reduced forms" recognizing test, learners were asked to listen carefully to 20 taped statements, and meanwhile fill in the blanks in their answer sheets with the complete forms of the words they heard. The 20 statements of the "reduced forms" recognizing test mainly manifested examples of assimilation, reduction, elision and contraction. The goal of using this fill in the blank test was to see whether the participants were able to recognize the "reduced words" in the spoken language they hear, and also to see if explicit instruction of the "reduced forms" will improve their ability to comprehend these forms.

"Reduced forms" Production test: In order to answer the third research question, a speaking test was used both as the pre-test and posttest. In the speaking test, the participants were asked to speak for 2 minutes, and meanwhile their speeches were recorded for later analysis. Learners were free to speak about every topic they were interested in. The scoring of the speaking test was based on the number of "reduced forms" produced by the participants. Using this test it was hoped to see whether the participants were able to produce the English "reduced forms" in their daily, informal dialogues.

\subsection{Procedure}

First, participants of both groups were given three pre-tests for checking their listening comprehension ability, their "reduced forms" recognition ability, and their "reduced forms" production ability. The pretests were used to see whether all the participants in both groups were homogenous in their knowledge of the items under investigation. After pretests, learners in experimental group were given instruction on "reduced forms", but learners in the control group just followed their regular instructions.

The instruction of the "reduced forms" included focusing learners' attention on the manifestations of sound changes, and explaining the phonological rules of "reduced forms" to help students understand how the mechanism of each type of "reduced forms" functions. After explaining the phonological rules of the "reduced forms", students did a few "reduced forms" exercises in hope of enhancing their retention of the knowledge of "reduced forms". The course was met twice a week. Every teaching session lasted for 35 minutes. The instruction of the experimental group continued for 10 weeks while the authors were responsible for the treatment of the experimental group. Table 3.1 in shows the detailed pattern of each 35- minute lesson performed for experimental group.

Table 2. Each session class activities performed for the experimental group

\begin{tabular}{llll}
\hline & Stage & Description & Time \\
\hline 1 & Pre- listening stage & $\begin{array}{l}\text { Unknown words, and phrases from the video clips were } \\
\text { explained and translated. }\end{array}$
\end{tabular}

Background information of the video clips was provided to increase learners' listening comprehension.

Guided questions or pictures were provided to focus students' attention on the main ideas of the video clips.

The goal of this stage was to make learners familiar with the topic they are going to hear. 
2 Listening comprehension Learners were presented with an aural text, and meanwhile they 7 minutes checking stage were asked to answer a few listening comprehension questions.

The aim was to check their comprehension of the main ideas of the language they heard.

3 Fill in the blank stage

Learners listened to a few short texts and sentences which included different types of the previously mentioned "reduced forms".

Learners were asked to fill in the blanks of their answer sheets with the complete forms of the "reduced forms" they heard.

4 Raising students' awareness of "reduced Learners were taught the "reduced forms" by focusing on the sound changes and the rules which they follow. forms"

5 "Reduced forms" Perception exercises

Learners were asked to write a few examples similar to those "reduced forms" which they were taught in that session.

The aim was to help learners to learn, and internalize those processes. So they could use, and understand better, the "reduced forms" of the language they heard.

6 "Reduced forms"

Learners were asked to work in pairs.

5 minutes Production exercises

In each session they were asked to choose a topic, and then speak about it in turn, using the previously taught "reduced forms" of English.

The aim of this stage was to enable the learners to produce the "reduced forms" in their speech.

6 minutes

7 minutes

5 minutes

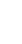

35 minutes

\begin{abstract}
After the treatment, subjects were given three post-tests for checking their possible amelioration in general listening comprehension ability, their "reduced forms" recognition the ability and their "reduced forms" production ability. Then, the results were compared between two groups and also with the participants' pretest results.
\end{abstract}

\title{
4. Data Analysis and Discussion
}

In order to answer the research questions, a control and an experimental group were formed from the Iranian EFL learners of Zaban-sara language institution. First, 3 pre-tests (for checking the participants' overall listening ability, their ability to recognize "reduced forms" and their ability to produce the "reduced forms" in their daily conversations) were administered to see if the participants of both groups were more or less at the same level of proficiency. After gaining certitude that the control and the experimental participants had not differed significantly in the referred aspects, a 10-week (two 35-minute sessions a week) listening course was conducted; the focus for the experimental group was on "reduced forms" training whereas the control group continued their regular listening class activities and drills offered by their course book. After 10 weeks, both groups took their post-tests to examine the existence of any improvements on the part of participants as the result of the 10-week "reduced forms" training course.

\subsection{Comparing the Two Groups on the Pre-Tests}

The study's pre-tests attempted to compare the participants of the study in three different but interrelated respects of English oral skills before the commencement of the study's treatment. Hence, accordingly, three pre-tests were designed and applied for the participants of the study. In order to examine the possible difference between the two groups' overall listening comprehension ability, a listening comprehension pre-test was administered. Employing three independent-samples $t$-tests, it was revealed that there was no statistically significant difference between these two group's performances on the "overall listening comprehension pre-test" $(\mathrm{p}=.713>.05)($ Table 3$)$, the "reduced-forms recognizing pre-test" $(\mathrm{p}=.495>.05)($ Table 4$)$ and the "reduced forms" production pre-test $(\mathrm{p}=.608>.05)($ Table 5$)$. 
Table 3. Mean comparison of the two group's performances on the "overall listening comprehension pre-tests"

\begin{tabular}{lllllll}
\hline & $\mathrm{N}$ & Mean & SD & t & df & Sig. \\
\hline Experimental participants & 25 & 7.44 & 1.41 & .370 & 48 & .713 \\
Control participants & 25 & 7.29 & 1.46 & & & \\
\hline
\end{tabular}

Table 4. Mean comparison of the two groups' performances on the "reduced forms recognition pre-test"

\begin{tabular}{lllllll}
\hline & $\mathrm{N}$ & Mean & $\mathrm{SD}$ & $\mathrm{t}$ & $\mathrm{df}$ & Sig. \\
\hline Experimental participants & 25 & 3.83 & .762 & -.687 & 48 & .495 \\
Control participants & 25 & 3.98 & .780 & & & \\
\hline
\end{tabular}

Table 5. Mean comparison of the two group's performances on the "producing "reduced forms" pre-test

\begin{tabular}{lllllll}
\hline & $\mathrm{N}$ & Mean & $\mathrm{SD}$ & $\mathrm{t}$ & $\mathrm{df}$ & Sig. \\
\hline Experimental participants & 25 & .60 & .54 & -.516 & 48 & .608 \\
Control group's participants & 25 & .68 & .56 & & & \\
\hline
\end{tabular}

To sum up, the three applied independent-samples $t$-tests revealed that participants of both groups were approximately similar in their listening ability in general and in "reduced forms" recognizing and producing, in particular.

\subsection{Performance of Participants of Both Groups on "Overall Listening Comprehension" Pre and Post-Test}

In order to scrutinize the difference between the experimental groups' performances on the pre and the post "overall listening comprehension" test, a paired-samples t-test was run. Likewise, another paired-samples t-test was run to examine the difference between the pre and post-test means of the control group. Descriptive analysis showed that, the means of both groups on the post-test were higher than that of theirs on the pre-test (Experimental: pre-test $=7.44$, post-test $=10.36 /$ Control: pre-test $=7.29$, post-test $=8.90)$. Tables 6 and 7 are the reports of the used paired-samples t-tests which reveal that there were significant differences between the experimental and the control participants performances on general listening comprehension pre and post-tests ( $p$ $=.000<.05$ ). As the results suggest, participants of both groups made statistically significant improvements in their overall listening comprehension ability after 10 weeks of general listening comprehension training.

Table 6. Mean comparison of the experimental group's "overall listening comprehension" pre and post-test"

\begin{tabular}{lllllll}
\hline & $\mathrm{N}$ & Mean & SD & $\mathrm{t}$ & $\mathrm{df}$ & Sig. \\
\hline Listening pre-test & 25 & 7.44 & 1.41 & -24.83 & 24 & .000 \\
Listening post-test & 25 & 10.36 & .62 & & & \\
\hline
\end{tabular}

Table 7. Mean comparison of the control group's "overall listening comprehension" pre and post-test

\begin{tabular}{lllllll}
\hline & $\mathrm{N}$ & Mean & $\mathrm{SD}$ & $\mathrm{t}$ & $\mathrm{df}$ & Sig. \\
\hline Listening pre-test & 25 & 7.29 & 1.45 & 13.78 & 24 & .000 \\
\hline Listening post-test & 25 & 8.90 & 1.82 & & & \\
\hline
\end{tabular}

\subsection{Performance of Participants of Both Groups on "Reduced Forms" Recognition Pre and Post-Test}

Descriptive statistics showed that the post-test mean of the experimental group on "reduced forms" recognizing was higher than its pre-test mean (pre-test $=3.83$, post-test $=5.56$ ) A paired-samples $t$-test was conducted to investigate if this difference was significant. As Table 8 indicates the experimental group made a significant improvement in the "reduced forms" recognizing post-test $(\mathrm{p}=.000<.05)$. Although the post-test mean of the control participants on "reduced forms" recognizing test was also higher than that of theirs on pre-test (pre-test $=$ 3.98., post-test $=4.10$ ) but as Table 9 indicates the control participants did not make a significant improvement 
in the "reduced forms" recognizing post-test $(p=0.161>.05)$. Therefore, without "reduced forms" instruction, the control participants did not improve as much as their peers in the experimental group in recognizing "reduced forms".

Table 8. Mean comparison of the experimental group's "reduced forms" recognition pre and post-test

\begin{tabular}{lllllll}
\hline & $\mathrm{N}$ & Mean & $\mathrm{SD}$ & $\mathrm{t}$ & $\mathrm{df}$ & Sig. \\
\hline Recognition pre-test & 25 & 3.83 & .762 & 24.5 & 24 & .000 \\
Recognition post-test & 25 & 5.56 & 1.04 & & & \\
\hline
\end{tabular}

Table 9. Mean comparison of the control group's "reduced forms" recognition pre and post-test

\begin{tabular}{lllllll}
\hline & $\mathrm{N}$ & Mean & $\mathrm{SD}$ & $\mathrm{t}$ & $\mathrm{df}$ & Sig. \\
\hline Recognition pre-test & 25 & 3.98 & .78 & -1.44 & 24 & .161 \\
Recognition post-test & 25 & 4.10 & .81 & & & \\
\hline
\end{tabular}

Therefore, a positive answer could be given to the second research question. That is, "reduced forms" practice was shown to be effective in increasing Iranian EFL learners" ability to understand "reduced forms".

\subsection{Performance of Participants of Both Groups on "Reduced Form Production" Pre and Post-Test}

According to the descriptive statistics, the post-test mean of the experimental group on producing "reduced forms" was higher than that of theirs on pre-test (pre-test $=0.60$, post-test $=1.96$ ). A paired-samples $t$-test was conducted to investigate if this difference was significant. Table 10 indicates that the experimental group made a significant improvement in the "reduced forms" production post-test $(p=.000<.05)$ which suggests the "reduced forms" instruction was effective in improving participants' "reduced forms" production. On the contrary, as Table 11 indicates, the control group did not make a significant improvement in the "reduced forms" producing post-test $(\mathrm{p}=.161>.05)$.

Table 10. Mean comparison of the experimental group's "reduced forms" production pre and post-test

\begin{tabular}{lllllll}
\hline & $\mathrm{N}$ & Mean & $\mathrm{SD}$ & $\mathrm{t}$ & $\mathrm{df}$ & Sig. \\
\hline Production pre-test & 25 & .60 & .54 & -30 & 24 & .000 \\
Production post-test & 25 & 1.96 & .38 & & & \\
\hline
\end{tabular}

Table 11. Mean comparison of the control group's "reduced forms" production pre and post-test

\begin{tabular}{lllllll}
\hline & $\mathrm{N}$ & Mean & $\mathrm{SD}$ & $\mathrm{t}$ & $\mathrm{df}$ & Sig. \\
\hline Producing pre-test & 25 & .68 & .56 & 1.45 & 24 & .161 \\
Producing post-test & 25 & .72 & .57 & & & \\
\hline
\end{tabular}

Therefore, a positive answer can be given to the third research question. That is, "reduced forms" practice could increase Iranian EFL learners' ability to produce "reduced forms" in their daily speech.

\subsection{Comparing the Two Groups on the Administered Post-Tests}

According to the results obtained, the post-test mean of the experimental group on "general listening comprehension" test was higher than the post-test mean of the control group. An independent-samples $t$-test was used to examine if this difference was significant. Table 12 reveals that there was a significant difference between these two group's performances in the "general listening comprehension" post-test $(p=0.003<.05)$ i.e., the experimental group significantly outperformed the control on this test. Consequently, it can be concluded that "reduced forms" practice was effective in increasing Iranian EFL learners' general listening comprehension ability. Therefore a positive answer could be given to the first research question. 
Table 12. Mean comparison of the two group's performances on the "general listening comprehension" post-tests

\begin{tabular}{lllllll}
\hline & $\mathrm{N}$ & Mean & $\mathrm{SD}$ & $\mathrm{t}$ & $\mathrm{df}$ & Sig. \\
\hline Experimental Listening post-test & 25 & 10.36 & .514 & 3.107 & 48 & .03 \\
Control Listening post-test & 25 & 8.90 & 1.825 & & & \\
\hline
\end{tabular}

Through employing another independent $t$-test it was revealed that there was a significant difference between the participants of two group's performances in the "reduced forms" recognition post-test $(p=0.000<.05)$; the experimental group significantly outperformed the control group on the "reduced forms" recognizing post-test, accordingly, a positive answer can be given to the second research question.

Table 13. Mean comparison of the two groups' performances on the "reduced forms recognition" post-test

\begin{tabular}{lllllll}
\hline & $\mathrm{N}$ & Mean & $\mathrm{SD}$ & $\mathrm{t}$ & $\mathrm{df}$ & Sig. \\
\hline Experimental participants & 25 & 5.56 & 1.04 & -5.88 & 48 & .000 \\
Control participants & 25 & 4.10 & .80 & & & \\
\hline
\end{tabular}

A third independent-samples $t$-test depicted that there was statistically significant difference between these two group's performances in the "reduced forms" production post-test $(p=0.000<.05)$. Since experimental group significantly outperformed the control group in the "reduced forms" producing post-test, it could be concluded that "reduced forms" practice was effective in increasing the learners" ability in producing the English "reduced forms" in their daily conversations. Hence, a positive answer could be given to the third research question.

Table 14. Mean comparison of the two group's performances on the "reduced forms" production post-test

\begin{tabular}{lllllll}
\hline & $\mathrm{N}$ & Mean & $\mathrm{SD}$ & $\mathrm{t}$ & $\mathrm{df}$ & Sig. \\
\hline Experimental participants & 25 & 1.96 & .37 & 8.77 & 48 & .000 \\
Control participants & 25 & .72 & .59 & & & \\
\hline
\end{tabular}

The role of listening comprehension in both communication and language acquisition is undeniable, however according to many (e.g., Brown, 1990; Ur, 1984), EFL learners have difficulties in understanding spoken language. Researchers suggest that one of the main reasons for this is appliance of numerous "reduced forms" in daily conversations which makes comprehension incredibly difficult for EFL learners. A few researchers have also investigated the effects of "reduced forms" instruction on learners' speaking ability. They believe that listening and speaking are closely related, and production of "reduced forms" not only makes learners' speech more fluent (Morely, 1991), but also has positive effects on their receptive skills (Hill \& Beebe, 1980). Inspired by the existing literature, this study tried to test the effect of English "reduced forms" instruction on general listening comprehension, "reduced forms" recognition and "reduced forms" production of a sample of Iranian EFL learners.

The comparison of the two groups' listening comprehension pre and post-test results revealed that both groups made significant improvements in their listening comprehension post-test, though the performance of the experimental group was better than the performance of the control group. The comparison of the two groups' pre and post-test results on recognizing and producing "reduced forms" tests also revealed that it was only the experimental group which significantly improved its "reduced forms" recognition and production. Hence, it was highly possible that "reduced forms" instruction was effective in raising the learners "reduced forms" understanding as well as their ability to produce them. The comparison of the two groups listening comprehension post-test results revealed that the experimental group was significantly better than the control group, and since the only difference between the two groups was accommodation of "reduced forms' instruction in the experimental class activities, it could be concluded that "reduced forms" instruction had even positive effect on general listening comprehension of the Iranian EFL learners. 


\section{Conclusion}

Listening comprehension has an important role in doing oral communication, since the ability to understand what others say is essential to communicative interaction. It is also believed that listening has a crucial role in language acquisition and language learning. Rankin (1929) explained that listening is the most frequently used language activity, since the average adult spends approximately three times as much time listening as reading. According to a research while communicating, adults spend $40-50 \%$ of communication time for listening, $25-30 \%$ for speaking, $9 \%$ for writing, and about for $11-16 \%$ reading (Rubin, 1994). Bird (1953) explained that college students spend $42 \%$ of their time in listening, $25 \%$ in speaking, $15 \%$ in reading and $18 \%$ in writing.

Listening comprehension is also the vulnerable spot of many Iranian EFL learners and as the result has drawn the attention of many Iranian researchers. According to some researchers (Jahangard, 2007; Hosseini 2007; Razmjo and Riazi, 2006), students' aural and oral skills are less emphasized in the Iranian prescribed EFL textbooks. Teachers put much less emphasis on oral drills, pronunciation, listening, and speaking abilities than on reading, writing, grammar, and vocabulary. Therefore, Iranian students face difficulties in using English language for communicative purposes. To help EFL learners improve their listening comprehension, researchers have investigated the effects of different factors. Among many suggestions the researchers seem to agree on the idea that "reduced forms" is one of the main reasons for unsuccessful interactions. To see this in practice, researchers have conducted a few studies in East Asian countries such as Japan, Taiwan and China. These studies mostly have investigated the effect of "reduced forms" instruction on improving overall listening comprehension of the EFL learners, increasing their "reduced forms" understanding as well as enabling them to produce and use them in daily speech.

Likewise, this study has investigated the effect of "reduced forms" training on increasing Iranian EFL learners' overall listening comprehension, "reduced forms" understanding, and also their ability of producing the "reduced forms", since it is believed that listening and speaking skills are closely inter-related. In order to answer the study research questions a total of 50 Iranian EFL learners were recruited and grouped as the experimental and control group of the study.

The pre/post-test results indicated that participants of both groups improved their general listening skills significantly at the end of the 10-week listening comprehension course. Results also showed that experimental participants had outperformed on "reduced forms" recognition and production tests than their peers in the control group as the result of the treatment they received during the course of study. These findings are in line with Brown and Hilferty's (1986) and Jia and fu (2011) who also confirmed the effectiveness of "reduced forms" instruction on increasing learners" "reduced forms" awareness. The results are also in line with Underwoods (2012) who also confirmed the effectiveness of "reduced forms" instruction on enhancing learners' ability of "reduced forms" production.

To recapitulate, all stakeholders, the administrators, curriculum designers, material developers, and teachers can draw on the findings of the present study to shape their curricula, create syllabi, develop materials, and conduct classes accordingly. To solve listening comprehension problem as the vulnerable spot of many Iranian EFL learners, the results of the present enquiry would be of utmost importance in that "reduced forms" training has positive effect not only on improving Iranian EFL learners' overall listening comprehension but also on producing native-like pieces of language.

\section{References}

Al-Musallam, E. I. (2009). College Instructors' and Learners' Attitudes to Authentic EFL Reading Materials in Saudi Arabia. (Unpublished M.A. thesis, University of Riadh: Saudi Arabia).

Anderson-Hsieh, J., Riney, T., \& Koehler, K. (1994). Connected speech modifications in the English of Japanese ESL learners. Issues and Developments in English and Applied Linguistics, 7, 31-52. http://dx.doi.org/10780/14/1/1003

Bird, D. E. (1953). Teaching Listening Comprehension. Journal of Communication, 3, 127-130. http://dx.doi.org/article/view/0205977988

Brown, G. (1990). Listening to Spoken English. London: Longman.

Brown, J. D. (1987). Patterns of English Pronunciation. Rowley, Mass: Newbury House.

Brown, J. D., \& Brown, K. K. (2007). Introducing connected Speech. In J. D. Brown, \& K. K. Brown (Eds.), Perspectives on Teaching Connected Speech to Second Language Speakers (pp. 1-15). Honolulu, HI: University of Hawai'i Press. 
Brown, J. D., \& Hilferty, A. G. (1986). The effectiveness of teaching reduced forms for listening comprehension. RELC Journal, 17(2), 59-70.

Brown, J. D., \& Kondo-Brown, K. (2006). Testing reduced forms. In J. D. Brown, \& K. K. Brown (Eds.), Perspectives on teaching connected speech to second language speakers (pp. 247-264). Honolulu, HI: University of Hawai'i, National Foreign Language Resource Center. http://dx.doi.org/9780824831363

Brown, G., \& Yule, G. (1983). Teaching the Spoken Language. New York: Cambridge University Press. http://dx.doi.org/ 10.1111/j.1467-9582.1981.tb00708

Cahill, R. (2006). Teaching reduced interrogative forms to low-level EFL students in Japan. In J. D. Brown, \& K. Kondo-Brown (Eds.), Perspectives on teaching connected speech to second language speakers (pp. 99-125). Honolulu, HI: University of Hawai'i, National Foreign Language Resource Center.

Celce-Murcia, M., Brinton, D., \& Goodwin, J. M. (1996). Teaching Pronunciation: A reference for teachers of English to speakers of other languages. Cambridge: New York: CUP.

Chamot, A. U., \& L. Kupper. (1989). Learning Strategies in Foreign Language Instruction. Cambridge: New York: CUP.

Chang, H. W. (2004). Teaching reduced forms to children of English as a Foreign Language. (Unpublished doctoral thesis, Providence University. Taichung: Taiwan).

Chen, S. W. (2002). Problems in listening comprehension for learners of ESL. Studies in English Language and Literature, 10, 57-70. http://dx.doi.org/ 31464475

Crystal, D. (1997). A Dictionary of Listening and Phonetics (4th ed.). Cambridge, MA: Blackwell Publishers.

Dauer, R., \& Browne, S. (1992). Teaching the pronunciation of connected speech. Paper presented at the $26^{\text {th }}$ annual meeting of TESOL, Vancouver, BC.

Field, J. (1997). Notes on Listening; Authenticity. Modern English Teacher, 6(3), 19-51.

Field, J. (1998). Skills and strategies: Toward a new methodology for listening. ELT Journal, 52(2), 110-118. http://dx.doi.org/10.1093/elt/52.2.110

Fujita, J. N. (1985). A preliminary inquiry into the successful and unsuccessful listening strategies of beginning college Japanese students. (Doctoral dissertation, The Ohio State University).

Goh, C. (1997). Meta-cognitive awareness and second language listeners. ELT Journal, 51, 361-369. http://dx.doi.org/10.1093/elt/51.4.315

Goh, C. (2002). Learners' self-reports on comprehension and learning strategies for listening. Asian Journal of English Language Teaching, 12, 46-68.

Henrichsen, L. E. (1984). Sandhi-variation: A filter of input for learners of ESL. Language Learning, 34, 103-126.

Herron, C., \& Seay, I. (1991). The effect of authentic oral texts on student listening comprehension in the foreign language classroom. Foreign Language Annals, 24(6), 487-495. http://dx.doi.org/10.1111/j.1944-9720.1991.tb00495

Hilferty, A. (1986). TESOL Techniques and Procedures. Boston, MA: Heinle \& Heinle Publishers.

Hill, C., \& Beebe, L. M. (1980). Contraction and blending: The use of orthographic clause in teaching pronunciation. TESOL Quarterly, 14, 299-323.

Hosseini, S. M. H. (2007). ELT in higher education in Iran and India - A critical view. Language in India, 7 , $1-11$.

Ito, Y. (2006). The comprehension of English reduced forms by second language learners and its effect on input-intake process. In J. D. Brown, \& K. Kondo-Brown (Eds.), Perspectives on teaching connected speech to second language speakers (pp. 67-81). Honolulu, HI: University of Hawai'i, National Foreign Language Resource Center.

Jahangard, A. (2007). Evaluation of EFL materials taught at Iranian public high schools. The Asian EFL Journal, 9(2), 130-150.

Jia, X., \& Fu, G. (2011). Strategies to Overcome Listening Obstacles and Improve the Listening Abilities. US-China Foreign Language, 9(5), 315-323.

Khalilisabet, M., \& Mahsefat, H. (2012). The Impact of Authentic Listening Materials on Elementary EFL 
Learners' Listening skills. International Journal of Applied Linguistics \& English Literature, 5, 23-45.

Kuo, F. L. (2012). Detecting ears for connected speech modification. Paper presented at 2011 NCUE Sixth Annual Conference on Language Teaching, Literature, Linguistics, Translation, and Interpretation, Changhua, Taiwan.

Mendelsohn, D. J. (1994). Learning to listen: A strategy-based approach for the second-language learner. San Diego, CA: Dominie Press.

Miller, M. (2005). Improving aural comprehension skills in EFL, using authentic materials: Experiment with university students in Nigata, Japan. (Unpublished master's thesis, University of Surrey, Australia. Conference, Hong Kong).

Moreira, M. L. (1996). On listening comprehension: Linguistic strategies used by second language learners $n$ non-collaborative course. (Unpublished Doctoral dissertation, University of Illinois at Urbana-Champaign).

Morley, J. (1991). The pronunciation component of teaching English to speakers of other languages. TESOL Quarterly, 25, 481-520. http://dx.doi.org/10.2307/3586981

Newton, J. (2009). Teaching ESL/ EFL Listening and speaking. New York: Routledge.

Norris, R. W. (1995). Teaching reduced forms: Putting the horse before the cart. English Teaching Forum, 33, 47-50.

Nunan, D. (1997). Listening in language learning. The Language Teacher, 23(9), 47-51. http://dx.doi.org/0320042004

O’Malley, J. M., Chamot, A. U., \& Kupper, L. (1989). Listening comprehension strategies in second language acquisition. Applied Linguistics, 29, 331-341. http://dx.do.org/ 10.1093/applin/10.4.418

Rankin, P. T. (1929). The importance of Listening Ability. English Journal, 17, 623-630.

Razmjo, S. A., \& Riazi, M. (2006). Is communicative language teaching practical in the expanding circle? A case study of teachers of Shiraz high schools and institutes. Journal of Language and Learning, 4(2), 144-171.

Richards, J. C. (2006). Curriculum development in language teaching. Cambridge University Press.

Richards, J. C., \& Renandya, W. A. (2002). Methodology in language teaching. Cambridge University Press.

Rivers, W. M. (1981). Teaching foreign language skills (2nd ed.). Chicago: University of Chicago Press.

Romanko, R. (2008). Whaddaya think about teaching reduced forms? Presentation at the JALT 2008 Annual Conference, Tokyo.

Rosa, M. (2002). Don'cha Know? A Survey of ESL Teachers! Perspectives on Reduced Forms Instruction? Second Language Studies, 21(1), 49-78.

Rost, M. (2001). Teaching and researching listening. London: Longman.

Rubin, J. (1994). A review of second language listening comprehension research. The Modern language journal, 78, 199-221. http://dx.doi.org/10.1111/j.1540-4781.1994.tb02034

Schmitt, N. (2002). An Introduction to Applied Linguistics. Oxford University Press.

Sun, K. C. (2002). Investigation of English listening difficulties of Taiwan students. The 11th conference on English Teaching and Learning in the Republic of China, 518-525. Taipei: Crane.

Thanajaro, J. L. (2000). Using authentic materials to develop listening comprehension in the English as a second language classroom, Virginia Polytechnic Institute and State University.

Ting, W. Y., \& Pierce, K. (2011). Messages behind the Unheard Sounds: Crossing the word Boundaries through Songs. NCUE Journal of Humanities, 5, 75-92. http://dx.doi.org./987654321/14472/1/2040000510006

Underwood, M. (2012). Teaching Listening. Longman publications.

Ur, P. (1984). Teaching Listening Comprehension. Cambridge: Cambridge University Press. http://dx.doi.org./10519/2626/1/KJ00004297307

Vandergrift, L. (1997). The Cinderella of communication strategies: Reception strategies in interactive listening. The Modern Language Journal, 81, 494-505. http://dx.doi.org./10.1111/j.1540-4781.1997.tb05517.x/

Vandergrift, L. (2002). It was nice to see that our predictions were right: Developing meta-cognition in L2 listening comprehension. Canadian Modern Language Review, 58, 556-575. http://dx.doi.org/10.3138/cmlr.58.4.555 
Vandergrift, L. (2005). Relationships among motivation orientations, meta-cognitive awareness and proficiency in L2 listening. Applied linguistics, 26, 70-89. http://dx.doi.org/10.1093/applin/amh 039

Vandergrift, L. (2007). Recent developments in second and foreign language listening. Language Teaching, 40, 191-210. http://dx.doi.org/10.1017/S0261444807004338

\section{Copyrights}

Copyright for this article is retained by the author(s), with first publication rights granted to the journal.

This is an open-access article distributed under the terms and conditions of the Creative Commons Attribution license (http://creativecommons.org/licenses/by/3.0/). 